\section{Mystery solved}

SIR-The miniature crossword that the Churchill Hospital team observed in their chromosome count was probably the remains of a pennate diatom. These organisms produce siliceous frustules which feature the regular pattern seen in their micrograph. The pattern is due to perforations, and if a proportion of them retain air-bubbles during mounting they would convey the crossword appearance, as tiny air-bubbles appear black in mounted

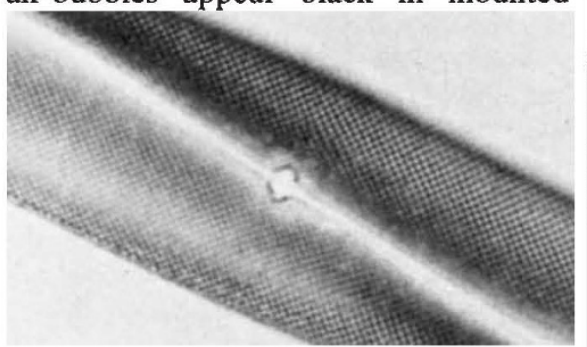

The answer to the crossword question posed in Nature of 25 September?

preparations. The fossilized remains of diatoms - as diatomite - are used as an absorbent (dynamite is composed of nitroglycerine and diatomite, for example). In the laboratory diatomite has been used in filters. None of this should discourage the adventurous wordsmith from writing clues for the puzzle, however, which would be a feat in itself.

Mill Park House,

BRIAN J. FORD

57 Westville Road,

Cardiff CF2 5DF, UK

SIR-Identification of the "mystery object amid the chromosomes" reported by Wolstenholme et al. ${ }^{1}$ was straightforward. More intriguing was what this object, clearly genetic in nature, could predict about the future of the individual amongst whose chromosomes it was found.

Sadly, the future is not bright. After 47 generations he (or she - only a part of the chromosome spread was visible) turns inescapably into a traffic light. That's Life ${ }^{2}$.

ANDREW BALL

Biochemistry Department and Biophyiscs

Laboratory,

University of Wisconsin,

Madison, Wisconsin 53706, USA

1. Wolstenholme, J. et al. Nature 323, 300 (1986)

2. Berlekamp, E., Conway, J.H. \& Guy, R. in Winning Ways Vol. 2 (Academic, New York, 1982)

\section{Turing's fly}

SIR-The view that compartmentalization $^{1}$ is a crucial event in early Drosophila development has frequently been proposed in this journal (see, for example refs 2 and 3). In a recent News and Views article North ${ }^{4}$ reported Meinhardt's suggestion $^{5}$ that imaginal disks are specified on the embryonic surface at the points of intersection of antero-posterior (A/P)

\section{and dorso-ventral (D/V) compartment} boundaries. This suggestion cannot be strictly true as the antennal disk, for example, is specified well before its $\mathrm{A} / \mathrm{P}$ compartment boundary, which is only established during the second larval instar ${ }^{6}$. No $\mathrm{D} / \mathrm{V}$ compartment boundary has been demonstrated in the antennal disk and even in the wing ${ }^{1}$ and leg $^{7}$ disks there are no D/V boundaries until late in development.

Whether lineage restrictions analogous to compartment boundaries do exist in the early embryo is a critical question. Clearly, the expression of fate-determining gene products such as those from Ultrabithorax (Ubx) and fushi-tarazu (ftz), as revealed by in situ hybridization, is restricted to discrete domains. In the case of $U b x$ the domain of expression cannot be compartment-specific because, as predicted by Lewis ${ }^{8}$, it extends across several segments, well into the posterior abdomen". Maximum expression of $U b x$, however, occurs within a sharply defined region between the middle of the third thoracic and the middle of the first abdominal segments. The boundaries of the domain of maximum expression probably do not represent lineage restrictions because, even by the end of larval development, such $\mathrm{A} / \mathrm{P}$ restrictions cannot be demonstrated in the larval cuticle ${ }^{10}$.

In the case of $\mathrm{ftz}$, the domains of expression cannot correspond to a discrete cell lineage because, at the beginning of gastrulation, the $\mathrm{ftz}$ domains contract from four to three nuclei in width whereas the $f t z^{-}$domains broaden ${ }^{11}$.

To some extent this argument is semantic: it is clear that there is a set of fatedetermining gene products that are expressed within discrete domains. It is these domains of expression, rather than the presence, or absence, of cell-lineage restrictions at their boundaries, which are critical. Where the problem really comes home to roost, however, is with the idea that these domains represent discrete units of pattern formation ${ }^{3}$. If this were the case, then we have a model that is capable of allocating cells to A or P compartments. However, in both the adult and embryonic ectoderm, the pattern of differentiated cell types indicates that the determination of regional fate is more precise than simply to a half-segmental region. If the fatedetermining gene products served only to allocate cells to discrete compartmental or "parasegmental" units, then a separate mechanism would be required to subdivide such units. An alternative possibility is that the discrete domains of these gene products overlap to give each row of cells along the $\mathrm{A} / \mathrm{P}$ axis of the embryo a unique "positional identity" 12 allowing a much more precise determination of regional $\mathrm{fate}^{13}$. There is no requirement for discrete units of pattern formation.

The question posed by Alan Turing, of how the information necessary to describe an adult organism is generated, is beginning to be answered.

Department of Genetics,

D. GuBB

University of Cambridge,

Cambridge CB2 3EH, UK

1. Garcia-Bellido, A., Ripoll, P. \& Morata, G. Nature 245, 251-253 (1975)

2. Morata, G. \& Lawrence, P.A. Nature 255, 614-617 (1975)

3. Martinez-Arias, A. \& Lawrence, P.A. Nature 313, 639-642 (1985).

4. North, G. Nature 322, 404-405 (1986).

5. Meinhardt, H. Devl Biol. 96, 375-385 (1983).

6. Strubl, G. Nature 270, 723-725 (1977).

7. Steiner, E. Wihelm roux' Archiv. 180, 9-30 (1976)

Lewis, E.B. Nature 276, 565-570 (1978).

9. Akam, M. EMBO J. 2, 2075-2084 (1983)

10. Szabad, J., Schubach, T. \& Wieschaus, E. Devi Biol. 73, 256-271 (1979).

11. Carroll, S.B. \& Scott. M.P. Cell 43, 47-57 (1985)

12. Gergen, J.P., Coulter, D. \& Wieschaus, E.F. in Gametoge nesis and the Early Embryo (ed. Gall, J.) (Liss, New York. in the press).

13. Gubb, D. BioEssays 2, 27-31 (1985)

\section{Imanishi's impact in Japan}

SIR-Beverly Halstead's ${ }^{1}$ commentary on Kinji Imanishi and anti-darwinian theory has prompted critical replies ${ }^{2-5}$ regarding some oddities in his conclusions. Halstead has in fact raised something of a red herring in considering only Imanishi's antidarwinism. His impact in Japan does not rest only or mainly on this. The emphasis on discussing Imanishi's evolutionary theory in the West stems partly from ongoing debates among evolutionists but also from the fact that there is little else written by or about the full extent of Imanishi's ideas in English. His evolutionary theory was introduced to an Englishspeaking audience in $1982^{6}$. The subsequent publication ${ }^{7.8}$ first alerted Halstead to Imanishi's theory and apparently set the parameters for his investigation.

Halstead states ${ }^{1}$ that “... in Japan the average intelligent layman's understanding of evolution stems in great measure from the writings of Imanishi". He nowhere indicates that he ever spoke to a sample of such people but given that darwinian theory was introduced to Japan in $1878^{9}$, that the Origin has been translated into Japanese in several editions since $1896^{10.11}$ and is taught in schools, it is doubtful that they are less cognizant of darwinism than their Western counterparts. In my experience it is Imanishi's early writings ${ }^{12}$ to which the general public refer when asked if they have read him. Those writings contain the kernel of ideas Imanishi later developed into his evolutionary theory, but they are also a combination of a philosophy, personal credo and natural history. His earliest book ${ }^{12}$, in particular, evocatively described ${ }^{13}$ as tamamushi (referring to an iridescent beetle whose colours change according to the angle from which it is seen), continues to give fresh insights today.

Scientists, too, have derived inspiration from these early books ${ }^{14}$. The concept of habitat segregation (sumiwake) influenced research by population ecologists 